\title{
PENINGKATAN KEMAMPUAN PEMECAHAN MASALAH MATEMATIKA SISWA KELAS VIII 1 SMP NEGERI 2 SINGARAJA MELALUI PENERAPAN STRATEGIROTATING TRIO EXCANGE (RTE) BERBANTUAN KARTU KERJA
}

\author{
S. A. P. K. Wangi, I. G. P. Suharta, I. N. Gita \\ Jurusan Pendidikan Matematika \\ Universitas Pendidikan Ganesha \\ Singaraja, Indonesia \\ e-mail: kertiwangi27@gmail.com; igpsuharta@yahoo.com; nyomangita@gmail.com
}

\begin{abstract}
Abstrak
Penelitian ini bertujuan untuk mengetahui peningkatan kemampuan pemecahan masalah matematika siswa melalui penerapan strategi pembelajaran RTE berbantuan kartu kerja. Penelitian ini adalah Penelitia Tindakan Kelas yang melibatkan subjek sebanyak 38 orang siswa Kelas VIII 1 SMP Negeri 2 Singaraja pada semester genap Tahun Pelajaran 2016/2017. Penelitian ini dilakukan dalam tiga siklus yang masing-masing terdiri atas tahap perencanaan, pelaksanaan tindakan, observasi/evaluasi serta refleksi. Pengumpulan data menggunakan metode wawancara, observasi dan tes. Keseluruhan data ini selanjutnya dianalisis secara deskriptif. Hasil penelitian menunjukkan kemampuan pemecahan masalah matematika siswa meningkat. Rata-rata skor kemampuan pemecahan masalah matematika siswa pada refleksi awal yaitu 38,33 pada siklus I rata-rata skor kemampuan pemecahan masalah matematika meningkat menjadi 48,65 meningkat lagi menjadi 65,2 pada siklus II dan meningkat menjadi 78,2 pada siklus III. Peningkatan tercapai setelah siswa melalui tahapan-tahapan pembelajaran dari penerapan strategi pembelajaran RTE berbantuan kartu kerja dengan beberapa penyempurnaan pada tindakan pembelajaran.
\end{abstract}

Kata kunci:Strategi Pembelajaran RTE, Kemampuan Pemecahan Masalah, Kartu Kerja

\begin{abstract}
This study aimed at knowing students' achievement of mathematics solving problem skill through the implementation of RTE learning strategies assisted work card. This study is classroom action research which involving 38 students of class VIII 1 SMP Negeri 2 Singaraja in even semester in the academic year 2017/2018 as subject. This study was done in three cycles, in which each cycle consisted of planning, acting, observing, and reflecting. The data were collected by using interview, observation and test. Then, the data were analyzed descriptively. The results of the study show that the students' achievement of mathematics solving problem skill increase. The average of students' mathematics solving problem score in the beginning reflection was 38,33 . In the first cycle, the average of students' mathematics solving problem score increased to 48,65. Then, in the second cycle, the average of students' mathematics solving problem score increased to 65,2. Finally in the third cycle, the average of students' mathematics solving problem score increased to 78,2 . The improvement is achieved after the students through the learning stages of applying the RTE learning strategy with the help of the work card with some improvement in the learning action.
\end{abstract}

Keywords :RTE Learning Strategies, Solving Problem Skill, Work Card

\section{Pendahuluan}

Pendidikan merupakan usaha terencana untuk meningkatkan kualitas manusia kearah yang lebih baik dan berguna untuk membantu dirinya sendiri, orang lain dan alam sekitarnya. Definisi pendidikan dalam Undang-undang Republik Indonesia nomor 20 tahun 2003 tentang Sistem Pendidikan Nasional Pasal 1 ayat (1) pendidikan adalah usaha sadar dan terencana untuk mewujudkan suasana belajar dan proses pembelajaran agar siswa secara aktif mengembangkan potensi dirinya untuk memiliki kekuatan spiritual keagamaan, pengendalian diri, kepribadian, kecerdasan akhlak mulia, serta keterampilan yang diperlukan dirinya, masyarakat, bangsa dan Negara (Depdiknas,2003). 
Salah satu mata pelajaran yang memiliki peran penting dalam meningkatkan mutu pendidikan yaitu matematika. "Matematika yang dipelajari melalui pendidikan formal (matematika sekolah) mempunyai peranan penting bagi siswa sebagai bekal pengetahuan untuk membentuk sikap serta pola pikirnya" (Suherman dkk, 2003:61). Oleh karena itu, matematika dipelajari disetiap jenjang pendidikan, mulai dari jenjang pendidikan dasar hingga perguruan tinggi.

Berdasarkan Permendiknas No 22 Tahun 2006 tentang Standar Isi untuk Satuan Pendidikan Dasar dan Menengah, pembelajaran matematika bertujuan agar peserta didik memiliki kemampuan : (1) Memahami konsep matematika, menjelaskan keterkaitan antar konsep dan mengaplikasikan konsep atau algoritma, secara luwes, akurat, efisien dan tepat dalam pemecahan masalah. (2) Menggunakan penalaran pada pola dan sifat, melakukan manipulasi matematika dalam membuat generalisasi, menyusun bukti, atau menjelaskan gagasan dan pernyataan matematika. (3) Memecahkan masalah yang meliputi kemampuan memahami masalah, merancang model matematika, menyelesaikan model dan menafsirkan solusi yang diperoleh. (4) Mengomunikasikan gagasan dengan simbol, tabel, diagram, atau media lain untuk memperjelas keadaan atau masalah. (5) Memiliki sikap menghargai kegunaan matematika dalam kehidupan, yaitu memiliki rasa ingin tahu, perhatian, dan minat dalam mempelajari matematika, serta sikap ulet serta percaya diri dalam pemecahan masalah. (Depdiknas, 2006:346)

Sejalan dengan itu, (NCTM, 2000) menetapkan lima standar kemampuan matematis yang harus dimiliki oleh siswa, yaitu kemampuan pemecahan masalah (problem solving), kemampuan komunikasi (communication), kemampuan koneksi (connection), kemampuan penalaran (reasoning), dan kemampuan representase (representation). Selanjutnya, Rusefendi (dalam Effendi) mengemukakan bahwa "kemampuan pemecahan masalah sangat penting dalam matematika, bukan saja bagi mereka yang di kemudian hari akan mendalami matematika atau mempelajari matematika, melainkan juga bagi mereka yang akan menerapkannya dalam bidang studi lain dan dalam kehidupan sehari-hari”.

Pemecahan masalah termuat pada tujuan pembelajaran matematika menurut Depdiknas (2006) dan lima dasar kemampuan matematis menurut NCTM. Artinya kemampuan pemecahan masalah merupakan kemampuan penting yang harus dikembangkan dan dimiliki oleh siswa. Mengingat betapa pentingnya tujuan pembelajaran matematika dalam kehidupan dan pengembangan pengetahuan, sudah sepantasnya konsep-konsep matematika perlu dikuasai dengan baik oleh siswa sehingga siswa mampu memecahkan masalah yang diberikan. Serta pelibatan siswa dalam proses pembelajaran sangat diperlukan dalam pemecahan masalah sehingga pembelajaran dapat berjalan dengan baik. Namun pada kenyataannya kemampuan pemecahan masalah matematika siswa merupakan salah satu masalah yang sering dialami setiap jenjang pendidikan. Rendahnya kemampuan pemecahan masalah matematika dialami oleh siswa kelas VIII 1 SMP Negeri 2 Singaraja. Hal ini berdasarkan hasil wawancara yang peneliti lakukan dengan guru yang mengajar matematika di kelas tersebut.

Untuk membuktikan hasil wawancara, peneliti mengadakan observasi di Kelas VIII 1 SMP Negeri 2 Singaraja, hasil dari observasi tersebut menunjukkan bahwa siswa mengalami kesulitan dalam memahami informasi yang diberikan untuk memecahkan masalah dan siswa juga tidak tahu darimana permasalahan diselesaikan. Seperti yang peneliti amati saat observasi di kelas tersebut, guru memberikan contoh soal yang ada di buku pegangan siswa dan siswa menyelesaikan soal yang ada di buku berdasarkan contoh yang diberikan sehingga kemampuan siswa dalam menyelesaikan masalah kurang karena masih terpaku pada contoh soal yang telah diajarkan. Kemudian guru memberikan sebuah soal cerita yang tidak ada pada buku, siswa kesulitan dalam menerjemahkan soal cerita ke dalam kalimat matematika.

Selain melakukan wawancara dan observasi, peneliti juga melakukan tes awal untuk mengetahui kemampuan pemecahan masalah, memilih strategi penyelesaian, menyelesaikan masalah dan memeriksa kembali yaitu dengan memberikan 2 butir soal tes pemecahan masalah kepada 38 siswa. Pada tes ini, penilaian kemampuan pemecahan 
masalah matematika siswa adalah berdasarkan kemampuan pemecahan masalah yang dikemukakan oleh Polya(Suherman, 2003) yaitu "(1) memahami masalah, (2) merencanakan pemecahannaya, (3) menyelesaikan masalah serta (4) memeriksa kembali”. Dari tes yang diberikan diperoleh hasil dari salah satu soal, yaitu siswa masih banyak yang belum dapat menyelesaikan masalah dengan baik. Hal ini terlihat jelas hanya 18,42\% siswa Kelas VIII 1 yang baru dapat memahami masalah, $21,05 \%$ siswa yang mampu merencanakan masalah, $31,57 \%$ siswa mampu melaksanakan penyelesaian masalah serta $0 \%$ siswa yang melakukan pemeriksaan kembali terhadap permasalahan yang diberikan. Dari penjelasan tersebut jelas bahwa kurang dari $50 \%$ siswa Kelas VIII 1 belum dapat mengidentifikasi permasalahan yang diberikan dan memecahkan masalah dengan benar.

Berdasarkan hasil wawancara, observasi dan tes awal yang peneliti lakukan diperoleh informasi bahwa kemampuan pemecahan masalah matematika siswa Kelas VIII 1 SMP Negeri 2 Singaraja masih rendah dan masih sangat perlu ditingkatkan, sehingga dibutuhkan strategi pembelajaran yang inovatif, salah satunya yaitu strategi Rotating Trio Exchange (RTE). Strategi RTE merupakan strategi yang digunakan dalam diskusi tentang berbagai masalah dengan beberapa teman sekelasnya. Dalam strategi ini, akan terjadi perputaran atau pertukaran anggota kelompok sehingga akan terbentuk kelompok - kelompok baru pada setiap pergantian masalah atau pertanyaan. Dengan adanya proses perputaran anggota kelompok dalam mengkonstruksi konsep matematika untuk dapat memecahkan masalah matematika tersebut, diharapkan dapat membangkitkan keaktifan siswa sehingga tercipta pembelajaran yang bermakna.

Berdasarkan deskripsi yang telah dikemukakan, maka perlu dilaksanakan suatu penelitian dengan menerapkan strategi RTE di kelas VIII 1 SMP Negeri 2 Singaraja. Dengan demikian diajukan Penelitian Tindakan Kelas yang berjudul "Peningkatan Kemampuan Pemecahan Masalah Matematika Siswa Kelas VIII 1 SMP Negeri 2 Singaraja Melalui Penerapan Strategi Rotating Trio Exchange (RTE) Berbantuan Kartu Kerja".

Adapun tujuan dari penelitian ini yaitu:Mendeskripsikan peningkatan kemampuan pemecahan masalah matematika siswa kelas VIII 1 SMP Negeri 2 Singaraja melalui penerapan strategi RTE berbantuan kartu kerja.

\section{Metode}

Jenis penelitian yang dilaksanakan merupakan jenis Penelitian Tindakan Kelas (Classroom Action Research). Penelitian ini secara umum bertujuan untuk meningkatkan dan memperbaiki proses pembelajaran di kelas VIII 1 SMP Negeri 2 Singaraja. Secara khusus penelitian ini untuk meningkatkan kemampuan pemecahan masalah matematika siswa kelas VIII 1 SMP Negeri 2 Singaraja melalui penerapan strategi RTE. Penelitian dilaksanakan dalam tiga siklus. Dalam setiap siklus terdiri dari empat langkah yaitu perencanaan tindakan, pelaksanaan tindakan, observasi, dan refleksi.

Penelitian dilaksanakan di SMP Negeri 2 Singaraja. Subjek penelitian ini adalah siswa kelas VIII 1 SMP Negeri 2 Singaraja semester genap tahun ajaran 2016/2017 sebanyak 38 siswa. Keterlibatan peneliti dalam penelitian ini adalah dalam bentuk kolaborasi antara peneliti dengan guru matematika kelas VIII 1 SMP Negeri 2 Singaraja. Kolaborasi yang dimaksud adalah peneliti bekerja sama dengan guru sehingga memungkinkan terjadinya pemahaman dan kesepakatan terhadap suatu masalah yang dihadapi serta pengambilan keputusan yang demokratis sehingga melahirkan kesamaan peresepsi terhadap tindakan yang dilakukan.

Tes yang digunakan untuk mengumpulkan data kemampuan pemecahan masalah matematika siswa yang berbentuk soal uraian (essay) sebanyak tiga soal. Tes ini dilaksanakan pada akhir setiap siklus. Tes kemampuan pemecahan masalah matematika ini digunakan untuk mengetahui kemampuan pemecahan masalah matematika siswa selama satu siklus yang digambarkan berupa skor setelah siswa tersebut mengerjakan tes. Sebelum digunakan, tes ini diuji validitas isi dan validitas susunannya melalui expert judgemen. Penilaian untuk setiap butir soal tes kemampuan pemecahan masalah matematis mengacu pada penilaian atau penskoran holistik. Penelitian melalui penerapan strategi RTE ini 
dikatakan berhasil jika memenuhi kriteria keberhasilan yaitu jika rata-rata skor kemampuan pemecahan masalah matematika siswa minimal pada kategori tinggi dan setiap siklusnya mengalami peningkatan.

\section{Hasil dan Pembahasan}

Ringkasan data kemampuan pemecahan masalah matematika siswa pada refleksi awal, siklus I, siklus II, dan siklus III dapat dilihat pada Table 1 berikut.

Tabel 1. Ringkasan Data Kemampuan Pemecahan Masalah Matematika

\begin{tabular}{|c|c|}
\hline Keterangan & Rata - rata \\
\hline $\begin{array}{c}\text { Refleksi } \\
\text { Awal }\end{array}$ & $\mathbf{3 8 , 3 3}$ \\
\hline Siklus I & $\mathbf{4 8 , 6 5}$ \\
\hline Siklus II & $\mathbf{6 5 , 2}$ \\
\hline Siklus III & $\mathbf{7 8 , 2}$ \\
\hline
\end{tabular}

Berdasarkan Tabel 1 di atas, secara umum terlihat bahwa kemampuan pemecahan masalah matematika siswa Kelas VIII 1 SMP Negeri 2 Singaraja mengalami peningkatan.

Setelah melaksanakan Penelitian Tindakan Kelas selama tiga siklus di Kelas VIII 1 SMP Negeri 2 Singaraja, hasil penelitian yang diperoleh adalah tentang peningkatan kemampuan pemecahan masalah matematika siswa. Tercapainya indikator keberhasilan penelitian yang ditetapkan yakni minimal kemampuan pemecahan masalah matematika ssiswa tergolong dalam kategori tinggi. Tentunya hal ini tidak terlepas dari pelaksanaan pembelajaran yang menerapkan strategi pembelajaran RTE.

Peningkatan kemampun pemecahan masalah matematika siswa yang terjadi di Kelas VIII 1 tersebut sangat dipengaruhi oleh strategi pembelajaran yaitu strategi pembelajaran RTE. Karena factor eksternal yang datang dari sekolah yang dapat mempengaruhi kemampuan pemecahan masalah matematika siswa adalah strategi pembelajaran yang digunakan. Hal - hal yang ada dalam strategi pembelajaran RTE berpengaruh terhadap peningkatan kemampuan pemecahan masalah matematika siswa diantaranya adalah pembentukan kelompok yang heterogen. Pembentukan kelompok secara heterogen dari segi kemampuan akademik bertujuan agar siswa tidak hanya belajar dari guru tetapi bisa belajar dari anggota kelompok yang kemampuan akademiknya lebih tinggi.

Selain itu, suasana pada pembelajaran strategi RTE menuntut siswa untuk selalu aktif selama pembelajran berlangsung, yakni aktif untuk menemukan penyelesaian dari masalah yang terdapat pada kartu kerja, aktif berinteraksi dengan guru dan siswa lain melalui kegiatan diskusi kelompok serta presentasi di depan kelas. Selama pembelajaran berlangsung guru bertindak sebagai fasilitator dan motivator, disamping memberikan kemudahan (fasilitas) belajar kepada siswa dan siswa berinteraksi dengan sumber-sumber belajar yang dapat mempermudah proses belajarnya. Jadi dalam pembelajaran dengan strategi RTE, aktivitas siswa mendominasi proses pembelajaran atau dengan kata lain pembelajaran berpusat pada siswa. Hal ini sesuai dengan pendapat Nasution (1995) yang menyatakan bahwa pengajaran modern mengutamakan aktivitas siswa. Demikian pula teori Bruner, yang menyatakan bahwa pembelajaran adalah siswa belajar melalui keterlibatan aktif dengan konsep dan prinsip-prinsip dalam mendapatkan pengelaman yang memungkinkan siswa menemukan dan memecahkan masalah.

Dengan menerapkan strategi pembelajaran RTE siswa dapat bekerja sama, saling membantu belajar informasi atau keterampilan dan adanya system penilaian dari peningkatan individu dengan bekerjasama dalam kelompok. Strategi pembelajaran RTE merupakan cara yang efektif untuk mengubah pola belajar dalam kelas. Strategi pembelajaran ini memiliki prosedur yang ditetapkan secara eksplisit untuk memberi siswa lebih banyak berpikir, menjawab dan saling membantu satu sama lain.

Pada strategi pembelajaran RTE yang diterapkan di Kelas VIII 1 SMP Negeri 2 Singaraja peneliti melakukan dua kali rotasi pada setiap pertemuan, dengan tiga kali 
pembentukan kelompok trio. Dengan pembentukan kelompok trio pertama akan diberikan soal yang mudah, agar siswa dapat dengan mudah menjawab pertanyaan tersebut. Kemudian dilanjutkan dengan merotasi agar terbentuk trio baru, siswa akan diberikan soal baru dengan tingkat kesukaran yang lebih tinggi. Begitu seterusnya hingga dua kali rotasi.

Peran guru dalam pembelajaran adalah sebagai fasilitator dan pembimbing, yaitu menyediakan kondisi yang kondusif bagi berlangsungnya proses pembelajaran dengan menyajikan masalah - masalah matematika sehingga siswa dapat memecahkannya. Dengan menerapka strategi pembelajaran RTE menjadikan kegiatan pembelajaran menjadi lebih bermakna.

Hasil penelitian ini sejalan denga hasil penelitian yang dikukan oleh Dipayana (2014) yang menyatakan bahwa kelompok yang dibelajarkan dengan strategi Rotating Trio Exchane memiliki hasil belajar yang lebih tinggi dibandingkan dengan kelompok siswa yang dibelajarkan dengan strategi pembelajaran kenvensional. Hal ini berarti, strategi pembelajaran RTE mampu memberikan kontribusi positif terhadap hasil belajar siswa. Selain itu, penelitian yang dilakukan oleh Nuraeni (2013) menunjukkan bahwa penerapan strategi Rotating Trio Exchange dapat meningkatkan kemampuan komunikasi matematis siswa.

Dari hasil penelitian tersebut, jika siswa dapat berkomunikasi matematis dengan baik setra dapat memperoleh hasil belajar yng tinggi maka siswa dapat berdiskusi kelompok dengan baik dan dapat bersama-sama memecahkan permasalahan yang diberikan.

\section{Simpulan dan Saran}

Berdasarkan hasil analisis data penelitian dan pembahasan yang telah diuraikan pada bab sebelumnya, dapat disimpulkan bahwa kemampuan pemecahan masalah matematika siswa mampu ditingkatkan melalui penerapan strategi pembelajaran RTE. Hal tersebut dapat tercapai dikarenakan dilakukan perbaikan pada tahap-tahap pembelajaran RTE yang dilakukan pada setiap siklus untuk penyempurnaan penerapan strategi RTE. Pada siklus I terlihat beberapa kendala yang menyebabkan belum optimalnya pembelajaran diantaranya siswa belum terbiasa berdiskusi dalam kelompok, siswa masih malu untuk menyampaikan pendapat, siswa masih belum terbiasa menyimpulkan materi pada akhir pembelajaran dan siswa belum mampu menyelesaikan masalah secara sistematis. Setelah menemukan kendala tersebut, peneliti dan Guru berdiskusi untuk melakukan tindakan perbaikan untuk dilaksanakan pada siklus II diantaranya memotivasi siswa untuk melakukan diskusi, menunjuk siswa untuk mengemukakan pendapat, memberikan pertanyaan - pertanyaan pancingan, melatih siswa menyelesaikan masalah secara sistematis. Setelah dilakukan tindakan pada siklus II terjadi peningkatan pada kemampuan pemecahan masalah siswa namun masih juga ditemukan kendala pada proses pembelajaran yaitu diskusi masih didominasi oleh beberapa siswa saja dan saat menyampaikan hasil diskusi didepan kelas masih didominasi oleh beberapa kelompok saja. Peneliti kembali berdiskusi untuk melakukan tindakan perbaikan yaitu dengan cara memberikan perhatian khusus pada kelompok yang anggotanya masih malu untuk mengajukan pendapat dan guru menunjuk secara acak kelompok dan perwakilannya untuk menyajikan hasil diskusinya di depan kelas. Setelah dilakukan tindakan pada siklus III terjadi peningkatan pada kemampuan pemecahan masalah siswa dan tidak ditemukan lagi kendala pada proses pelaksanaan pembelajarannya. Dapat dilihat pada siklus III bahwa pelaksanaan pembelajaran sudah sesuai dengan rencana yang direncanakan, pelaksanaan diskusi sudah membaik tidak didominasi oleh beberapa siswa saja, serta sudah banyak siswa yang mampu menyelesaikan permasalahan secara sistematis. Berdasarkan pemaparan tersebut penerapan strategi pembelajaran RTE berbantuan kartu kerja mampu meningkatkan kemampuan pemecahan masalah matematika siswa.

Berdasarkan temuan-temuan yang diperoleh dalam penelitian ini, dapat diajukan beberapa saran sebagai berikut. 1. Sebagai alternatif penggunaan strategi pembelajaran dalam pelaksanaan pembelajaran matematika, strategi pembelajaran RTE dapat dipertimbangkan untuk digunakan. Dengan demikian pembelajaran matematika berlangsung secara lebih bermakna dan tidak monoton serta nantinya dapat meningkatkan kemampuan 
pemecahan masalah matematika siswa. 2. Bagi pembaca yang berminat untuk melaksanakan penelitian lebih lanjut dengan strategi pembelajaran RTE diharapkan agar memperhatikan kendala-kendala yang dialami selama pelaksanaan penelitian ini sebagai bahan pertimbangan untuk perbaikan dan penyempurnaan pelaksanaan penelitian. Strategi pembelajaran RTE dapat pula dipertimbangkan untuk meningkatkan apek kognitif lain dalam pembelajaran matematika.

\section{Daftar Pustaka}

Arikunto, S. 2006. Penelitian Tindakan Kelas. Jakarta : PT. BumiAksara.

Candiasa, I Made. 2010. Statistik Univariat dan Bivariat Disertai Aplikasi SPSS. Singaraja : UNDIKSHA.

Dimyati dan Mudjiono. 1994. Belajar dan Pembelajaran Jakarta: Depdikbud.

Djamarah, S.B dan Zain, A. 2010. Strategi Belajar Mengajar. Jakarta: Rineka Cipta.

Effendi, L. A."Pembelajaran Matematika Dengan metode Penemuan Terbimbing Untuk Meningkatkan Kemampuan Representasi dan Pemecahan Masalah Matematis Siswa SMP". Tersedia pada. http://jurnal.upi.edu/file/6_Leo_Adhar_Effendi.pdf.

Gunawan, I. M. A. 2014. Peningkatan Kemampuan Pemecahan Masalah Dan Apresiasi Matematika Siswa Kelas VII-1 SMP Laboraturium Undiksha Singaraja Melalui Penerapan Model Pembelajaran Penemuan Terbimbing. Skripsi. (tidak diterbitkan). Fakultas Matematika dan IImu Pengetahuan Alam, Undiksha Singaraja.

Herman, H. 2003. Strategi Pembelajaran Matematika Kontemporer. Bandung: Universitas Pendidikan Indonesia.

Mardiani, Ni Nengah. 2015. Peningkatan Kemampuan Pemecahan Masalah dan Aktivitas Belajar Matematika Siswa Kelas VIII 14 SMP Negeri 2 Singaraja Melalui Penerapan Model Pembelajaran TSOI (Translating, Sculpting, Operationalizing, Integrating). Skripsi (tidak diterbitkan). Jurusan Pendidikan Matematika, Universitas Pedidikan Ganesha.

Nadia, 2013. "Teori Pemecahan Masalah". Tersedia pada. http://www.slideshare.net/nadiahbsa/teori-polya.

Nasution, S. 1995. Didaktik Asas-Asas Mengajar. Jakarta: Bumi Aksara.

NCTM. 2000. Mathematics Assessment: A Practical Handbook for Grades 6-8. USA: LCC

Permendiknas No 22 Tahun 2006 Tentang Standar Isi. 2006. Jakarta: Depdiknas.

Suci, A. A. W., \& Rosyidi, A. H. "Kemampuan Pemecahan Masalah Matematika Siswa Pada Pembelajran Problem Posing Berkelompok". Tersedia Pada. http://www.scribd.com/doc/122892042/KEMAMPUAN -PEMECAHAN-MASALAHMATEMATIKA-SISWA-PADA-PEMBELAJARAN-PROBLEM-POSINGBERKELOMPOK\#scribd

Suherman, dkk. 2003. Strategi Pembelajaran Matematika Kontenporer. Bandung: Universitas Pendidikan Indonesia.

Wardhani, S. 2008. Paket Fasilitasi Pemberdayaan KKG/MGMP Matematika: Analisis SI dan SKL Mata Pelajaran Matematika SMP/MTs Untuk Optimalisasi Tujuan Mata Pelajaran Matematika. Yogyakarta: P4TK Matematika.

Widhiastuti, Ni Ketut. 2014. Penerapan Metode Scramble untuk Meningkatkan Kemampuan Pemecahan Masalah Matematika Siswa Kelas VII B5 SMP Negeri 6 Singaraja. Skripsi (tidak diterbitkan). Jurusan Pendidikan Matematika, Universitas Pendidikan Ganesha.

Wulandari, F.D.P. 2013. "Pengaruh Model Pembelajaran Aktif Melalui Strategi Rotating Trio Exchange Terhadap Prestasi Belajar Siswa Pada Sub Pokok Bahasan Optik Geometris Kelas VIII Di SMP Negeri 30 Surabaya". Jurnal Inofasi Pendidikan Fisika,Vol. 02. No. 03, 6-10 